\title{
Analisis Perancangan Sistem Informasi Pendaftaran Siswa Baru pada SMK Taman Siswa Kisaran Menggunakan Web
}

\author{
Sudarmin \\ Program Studi Sistem Informasi, STMIK Royal Kisaran \\ email: edisudarmindra@gmail.com
}

\begin{abstract}
Information technology in everyday life is increasingly important because technological developments are increasing. The use of information technology in companies and the business world is very eradicating humans in the completion of fast and precise work. World Educational institutions are currently implementing information technology to support administrative work processes to support activities quickly and computerized. With a computerized system, it can provide good and effective services for the school. Taman Siswa Kisaran Private Vocational School is an educational institution that has a role to help educate the nation's children, still using computer technology that uses Microsoft Word and excel computers to manage new student admission compilation data using manual systems, making work efficiency in processing new student admission data must be accepted by this educational institution, information systems are expected to be able to improve public performance and efficiency in processing new student admissions data in making reports more efficient and accurate in the Taman Siswa K Private Vocational School.
\end{abstract}

Keywords: Php, MySQL, Information System

\begin{abstract}
Abstrak: Peranan teknologi informasi dalam kehidupan sehari-hari sangatlah penting karena perkembangan teknologi sudah semakin pesat. Penggunaan teknologi informasi di perusahaan dan dunia bisnis sangat membatuh manusia dalam menyelesaikan pekerjaan secara cepat dan tepat. Dunia Institusi pendidikanpun saat ini sedang menerapkan teknologi informasi sebagai sarana untuk mendukung proses pekerjaan tenaga administrasi untuk menyelesaian aktivitas dengan cepat dan terkomputerisasi. Dengan adanya sistem yang terkomputerisasi maka dapat memberikan pelayanan yang baik dan efesien khususnya untuk pihak sekolah. SMK Swasta Taman Siswa Kisaran adalah suatu lembaga pendidikan yang memiliki peran membantu mencerdaskan anak bangsa, masih memanfaatkan teknologi komputer secara sederhana seperti penggunaan aplikasi Microsoft word dan excel untuk pengolahan data-data ketika penerimaan siswa baru berlangsung hanya dengan menggunakan sistem manual, sehingga efesiensi kerja dalam pengolahan data penerimaan siswa baru belum didapatkan oleh instansi pendidikan ini, sistem informasi diharapkan mampu meningkatkan pelyanan publik dan efesiensi kerja terutama dalam pengolahan data penerimaan siswa baru dalam membuat laporan yang lebih efesien dan akurat pada SMK Swasta Taman Siswa Kisaran.
\end{abstract}

Kata Kunci : Php, MySQL, Sistem Informasi

\section{PENDAHULUAN}

Pesatnya r perkembangan
teknologi seiring dengan kemajuan
informasi menuntut manusia untuk
melangkah lebih maju mengimbangi

kedua hal tersebut, waktu pun dirasakan menjadi sangat berharga dimana segala aktivitas yang sudah dibuat sebelumnya dan bilamana kita tidak merancang rencana atau planning yang akan kita lakukan 
JURTEKSI (Jurnal Teknologi dan Sistem Informasi)

Vol. V No. 1, Des 2018, hlm. 59 - 62

DOI: https://doi.org/10.33330/jurteksi.v5i1.298

Available online at http://jurnal.stmikroyal.ac.id/index.php/jurteksi

kedepan maka dipastikan akan banyak waktu yang terbuang begitu saja. Kemudahan yang diperoleh dalam melaksnakan segala aktivitas, sehingga waktu yang dipakai menjadi efisien merupakan sesuatu yang tidak kalah penting di era globalisasi seperti saat ini dan solusi yang akan menjawabnya adalah internet. SMK Swasta Taman Siswa Kisaran adalah merupakan Institusi pendidikan kejuruan yang menyiapkan siswanya memiliki kemampuan untuk bisa bersaing dalam dunia kerja. Sehingga perlu peningkatan sumber daya manusianya, sarana dan prasarananya serta pemanfaatan teknologi untuk meningkatkan pelayanan di SMK Taman Siswa Kisaran khususnya dalam penyebaran informasi dan pelayanan pendaftaran siswa barunya dapat dilakukan tanpa mengenal waktu dan tempat dengan memanfaat teknologi komputer.

\section{Perancangan}

"Perancangan adalah suatu kegiatan yang memiliki tujuan untuk mendesign sistem baru yang dapat menyelesaikan masalah-masalah yang dihadapi perusahaan yang diperoleh dari pemilihan alternatif sistem yang terbaik" [1].

\section{Sistem}

Menurut Lucas bahwa sistem adalah sebagai suatu komponen atau variabel yang terorganisir, saling berinteraksi, saling bergantung satu dengan yang lain dan terpadu[1]

\section{Informasi}

Informasi adalah data yang telah diolah menjadi bentuk yang lebih berarti bagi yang penerimanya [2]. Data merupakan bentuk yang masih mentah yang belum dapat bercerita banyak, sehingga perlu diolah lebih yaitu :

a. Akurat

c. Relevan perusahaan.

\section{Sistem Informasi} perlukan [2].

\section{Website}

ISSN 2407-1811 (Print)

ISSN 2550-0201 (Online)

lanjut. Data diolah suatu model untuk dihasilkan menjadi informasi. Dalam sistem informasi kualitas dari suatu informasi tergantung pada tiga hal,

Informasi harus bebas dari kesalahankesalahan dan tidak menyesatkan. Akurat juga berarti informasi yang harus jelas mencerminkan maksudnya. Informasi harus akurat karena dari sumber informasi sampai ke penerima informasi kemungkinan banyak terjadi gangguan (noise) yang dapat merubah atau merusak informasi tersebut.

b. Tepat pada waktunya Informasi yang datang pada penerima tidak boleh terlambat, karena informasi merupakan landasan didalam mengambil keputusan.

Informasi yang mempunyai manfaat untuk pemakainya. Relevansi informasi untuk tiap-tiap orang satu dengan yang lainnya berbeda. Misalnya informasi mengenai sebab terjadinya kerusakan mesin produksi kepada akuntan perusahaan adalah kurang relevan dan akan lebih relevan bila ditunjukkan kepada ahli teknik

Sistem informasi adalah suatu sistem di dalam organisasi yang mempertemukan kebutuhan pengolahan transaksi harian, mendukung operasi, bersifat manajerial dan kegiatan strategi dari suatu organisasi dan menyediakan pihak luar tertentu dengan laporan-laporan yang di

World Wide Web (W3) atau yang dikenal juga dengan istilah web adalah suatu sistem yang berkaitan dengan dokumen digunakan sebagai media 
JURTEKSI (Jurnal Teknologi dan Sistem Informasi)

Vol. V No. 1, Des 2018, hlm. 59 - 62

DOI: https://doi.org/10.33330/jurteksi.v5i1.298

Available online at http://jurnal.stmikroyal.ac.id/index.php/jurteksi

untuk menampilkan teks, gambar, multimedia dan lainnya pada jaringan internet [3].

\section{ANALISA DAN HASIL}

Analisis sistem yang sedang disusun pada prinsipnya adalah mempelajari sistem yang ada dengan melakukan penelitian dan pengamatan terhadap sistem proses pendaftaran siswa baru dan penyebaran informasi di SMK Swasta Taman Siswa Kisara. Hal ini bertujuan untuk mempermudah prosedur sistem penerimaan siswa baru dan memudahkan dalam penyebaran informasi sekolah sehingga menghasilkan suatu pengembangan sistem baru. SMK Taman Siswa Kisaran merupakan Institusi yang bergerak di bidang pendidikan yang dalamnya proses penerimaan siswa baru, melibatkan tenaga kependidikan seperti pegawai administrasi, dan kepala sekolah selaku pimpinan sekolah. Dalam setiap melakukan proses penginputan data siswa baru yang akan mendaftar masih menggunakan sistem secara manual, sehingga dari mekanisme dan prosedur yang dilakukan mendapatkan suatu kendala diantaranya memperlambat cara kerja bagian administrasi, pendaftaran siswa baru dilakukan secara langsung dengan mendatangi sekolah.

\section{Context Diagram (CD)}

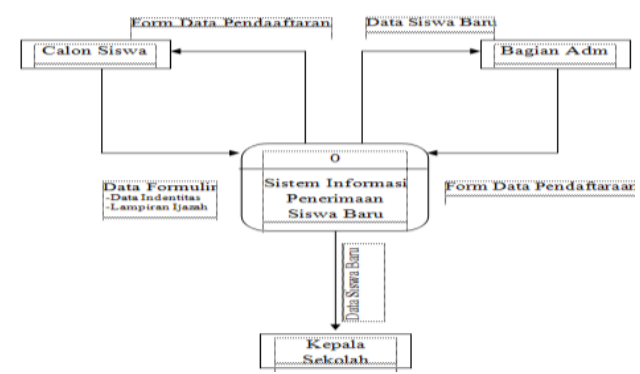

Gambar 1. Context Diagram (CD)
ISSN 2407-1811 (Print)

ISSN 2550-0201 (Online)

\section{Data Flow Diagram (DFD)}

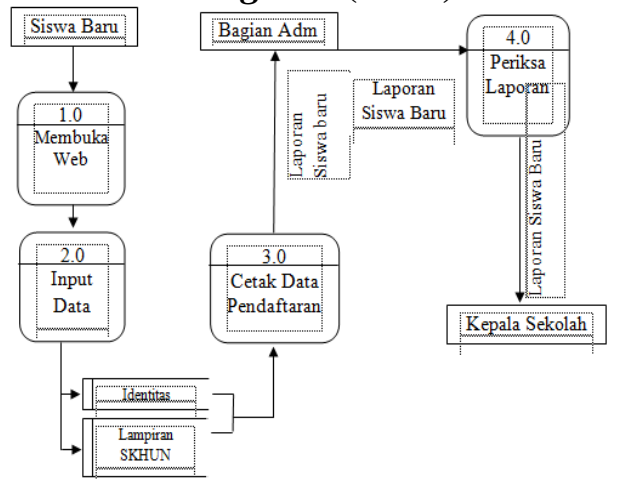

Gambar 2. Data Flow Diagram

\section{Entity Relationship Diagram (ERD)}

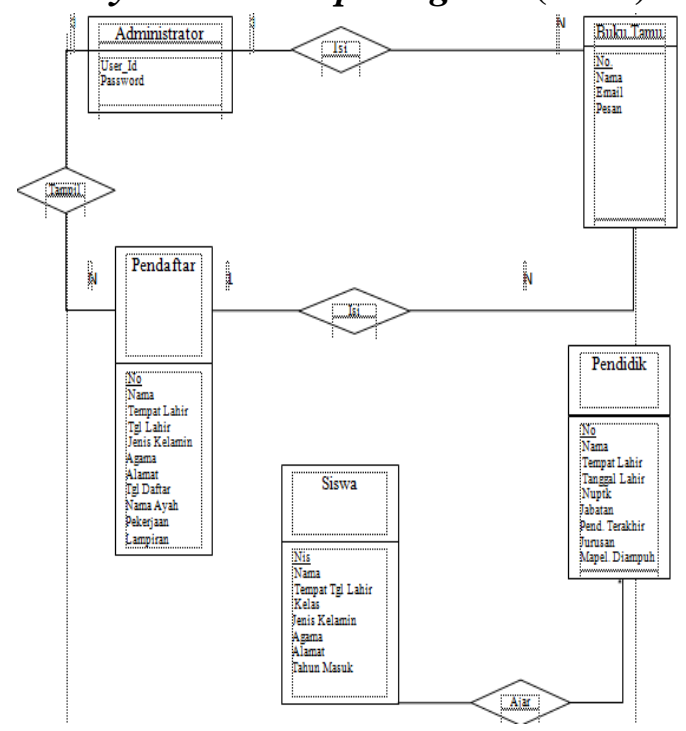

Gambar 3. Entity Relationship Diagram

\section{Struktur Program}

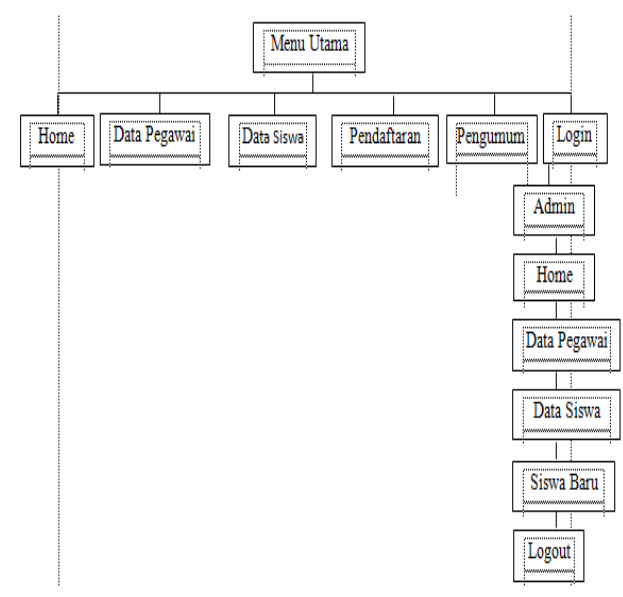

Gambar 4. Struktur Program 
JURTEKSI (Jurnal Teknologi dan Sistem Informasi)

Vol. V No. 1, Des 2018, hlm. 59 - 62

DOI: https://doi.org/10.33330/jurteksi.v5i1.298

Available online at http://jurnal.stmikroyal.ac.id/index.php/jurteksi

\section{Implementasi}

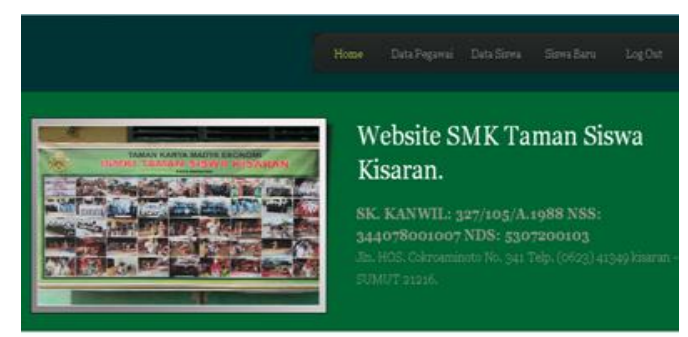

Selamat Datang di WEBSITE ini:

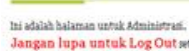

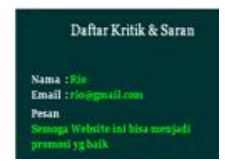

Gambar 5. Halaman Utama

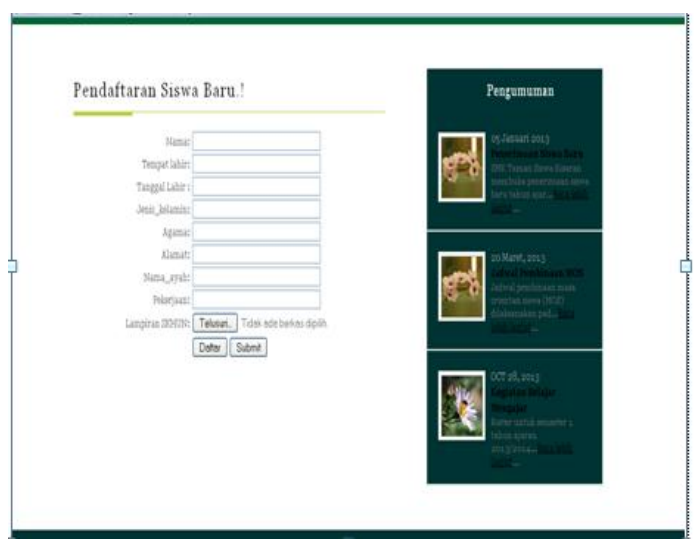

Gambar 6. Halaman Pendaftran Siswa Baru

\section{SIMPULAN}

Dari hasil pembahasan analisis perancangan sistem informasi pendaftaran siswa baru pada SMK Taman Siswa Kisaran menggunakan web sehingga dapat diambil kesimpulan sebagai berikut:

1. dengan adanya sistem informasi pendaftaran siswa baru pada SMK Swasta Taman Siswa Kisaran menggunakan web dapat mempermudah tenaga administrasi dalam proses pengolahan data siswa baru secara cepat dan akurat.

2. sistem informasi pendaftaran siswa baru dapat mempermudah siswa baru untuk mencari informasi secara online mengenai sekolah
SMK Swasta Taman Siswa Kisaran dan mempermudah siswa baru untuk melakukan pendaftran secara online.

\section{DAFTAR PUSTAKA}

[1] Betha Sidik, Ir \& Husni Iskandar Pohan, Ir. M.Eng. 2010 Pemrograman Web dengan HTML. Bandung Informatika.

[2] Jogiyanto, H.M., 2005, Analisa dan Desain Sistem Informasi: Pendekatan Terstruktur Teori dan Praktik Aplikasi Bisnis, ANDI, Yogyakarta.

[3] F. K. Sibero, Alexander. 2011. Kitab Suci Web Programming. Yogyakarta: Media Kom. 